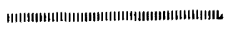 \\ 論 文 \\ UDC $669.12: 539.4: 013.3: 620.171 .313: 620.171 .32$

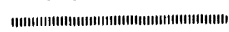 \\ 純鉄切欠試験片の破壊挙動*
}

\author{
中村 正久 ${ }^{* *}$. 坂木 庸晃 ${ }^{* *}$. 呂 芳一***
}

\section{The Fracture Behavior of Notched Specimen of Iron}

Tadahisa Nakamura, Tsuneaki SAKAKI, and Yoshikazu Ro

Synopsis:

Low temperature brittleness of vacuum-melted iron was studied through the evaluation of the fracture toughness, critical COD, and yield stress of smooth specimens as a function of testing temperature ranging from $20^{\circ}$ to $-269^{\circ} \mathrm{C}$ at static and dynamic tensile rates. The mode of fracture of notched specimens was also investigated in a scanning electron microscope.

The results obtained were as followed:

(1) The ductile-brittle transition temperatures determined by the cleavage percent of $75 \%$ were $-122^{\circ},-68^{\circ}$, and $-48^{\circ} \mathrm{C}$ for specimens tested at deformation rates $0.5 \mathrm{~mm} / \mathrm{min}, 2 \mathrm{~m} / \mathrm{sec}$, and $10 \mathrm{~m} / \mathrm{sec}$, respectively.

(2) The fracture strength of notched specimens was decreased with lowering the testing temperature below a critical temperature, which was equal to or somewhat lower the transition temperature determined from the above.

(3) The fracture toughness obtained showed temperature and tensile rate dependences; it was decreased with lowering temperature and with increasing the tensile rate.

(4) The ratio of critical COD to yield stress against the normalized stress fell on a curve for all specimens tested and the critical COD observed was larger than that calculated after Wells or BCS models.

(5) The incipient cleavage crack formed in notched specimens tested at low temperatures was often observed to start at a point of a few grains inner from the notch root.

(6) The effective surface energy calculated from the fracture toughness was from $1.5 \times 10^{6}$ to $1 \times 10^{7}$ $\mathrm{erg} / \mathrm{cm}^{2}$, which was about one hundred times larger than that obtained from the dislocation theory of the ductile-brittle transition temperature.

(Received Nov. 30, 1973)

\section{1. 緒言}

純鉄は，比較的高い温度では，繊維状の破面をもつ延 性破壊をするが低温になると，ある遷移温度域を境とし， へき開破壊をする1．ひずみ速度を大きくすると，同一 温度に対する降伏応力が著しく上昇し，遷移温度もより 高温側に移る2). 多結晶純鉄の破壊に関する研究として は, РетсH がへき開強度と粒径の関係を3)，CoHEN 5 がへき開の発生機棈を(， PUGH らがひずみ速度5)の影 響を調べている.

いつぽう, IRWIN らは, Griffith-Orowan の理論に基 ゔいて線形破壤力学67)を，をた，WELLS，BILBY らは COD 理諭8)9) を提案した.

この論文の目的は，純鉄の薄板を用い，ひずみ速度お よび温度を広範囲に变化させて引張り, 破壊挙動を $\mathrm{K}$ 值, COD 值を用いて調査し, これらのクライテリオン
と, ひずみ速度, 遷移温度との関係を調べることである． また, 破面とくに破壊発生源付近を観察し, さらに Cottrell, Petch らの延性脆性遷移温度理論10)11)上の 関連についても考察した。

\section{2. 実 験 方 法}

実験に使用した純鉄は，電解鉄を真空溶解カーボン脱 酸したもので，この鋳塊を熱間鉒造後，約 $80 \%$ の冷間 压延によつて, 厚さ $2.5 \mathrm{~mm}$ の板とした. 化学成分を Table 1 に示す. この冷間圧延板より, Fig. 1 に示す平 滑および両側 2 層切欠試験片を製作した. 試験片の平行 部長さは，それぞれ， $25 \mathrm{~mm}$ および $60 \mathrm{~mm}$ である.つ

\footnotetext{
* 昭和 48 年 4 月本会講演大会にて発表 昭和 48 年 11 月 30 日受付

** 東京工業大学金属工学科 工博

*** 東京工業大学大学院
} 
Table 1. Chemical composition. (wt \%)

\begin{tabular}{c|c|c|c|c|c|c}
\hline $\mathrm{C}$ & $\mathrm{N}$ & $\mathrm{O}$ & $\mathrm{Si}$ & $\mathrm{Mn}$ & $\mathrm{P}$ & $\mathrm{S}$ \\
\hline 0.007 & 0.002 & 0.00024 & 0.001 & 0.003 & 0.003 & 0.005 \\
\hline
\end{tabular}
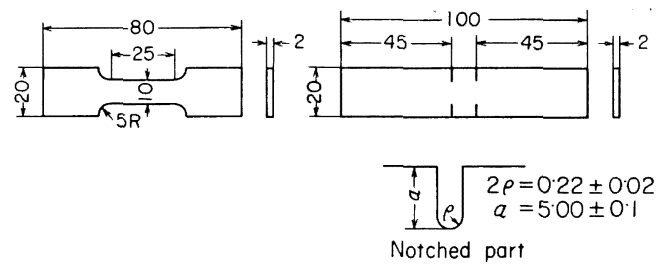

Fig. 1. Dimension of specimens.

ぎに，圧延集合組織を除去するためにつぎのような真空 焼鈍を行なつた。すなわち $910^{\circ} \pm 20^{\circ} \mathrm{C}$ の間で 3 回に わたり温度を上下させ $\alpha-\gamma$ 域を往復させて，全体で約 $1 \mathrm{hr}$ の加熱後徐冷し方位をランダムにした．この状態に おける平均結晶粒径は， $202 \mu$ であつた．静的引張試験 については，インストロン型引張試験機を用い，クロス ヘッド速度を $0.5 \mathrm{~mm} / \min$ (平滑試験片について平均ひ ずみ速度 $\left.3.33 \times 10^{-4} \mathrm{sec}^{-1}\right)$ とし, 室温, $-78^{\circ},-100^{\circ}$, $-120^{\circ},-140^{\circ},-155^{\circ},-183^{\circ},-196^{\circ}$ および -269 ${ }^{\circ} \mathrm{C}$ の 9 種の温度で試験した. 衝撃試験については回転 円盤式高速衝慗引張試験機を用いて引張速度を $2 \mathrm{~m} / \mathrm{sec}$ (平均ひずみ速度 $8.00 \times 10 \mathrm{sec}^{-1}$ ) および $10 \mathrm{~m} / \mathrm{sec}$ (平 均ひずみ速度 $\left.4.00 \times 10^{2} \mathrm{sec}^{-1}\right)$ とし室温, $-30^{\circ}$, $50^{\circ},-78^{\circ},-110^{\circ}\left(10 \mathrm{~m} / \mathrm{sec}\right.$ では $\left.-105^{\circ}\right),-135^{\circ}$, - $165^{\circ}$, および $-196^{\circ} \mathrm{C}$ の 8 種の温度で試験した. こ れらの実験から, 平滑試験片の降伏応力破壊応力などの 引張特性值を求め, 切欠試験片については破壊応力を求 め，遷移温度より低温側での破壞靶性值 $K_{c}$ を計算し た. また遷移温度付近の延性的な場合を含めて破壊の有 効なクライテリアとして知られている限界 COD 值 $\Phi_{c}$ を, 破断試験片の分離しなかつた一組の切欠部の変形を 測定して求内た。

つぎに破断試験片の破面を走査型電子顕微鏡を用いて 観察し, 破面遷移温度を求め, とくにへき開クラックの 発生場所を調べた.

\section{3. 実験結果および考察}

\section{1 降伏・破壊応力および选移温度}

Fig. 2 (a)（b）（c）に前述した $0.5 \mathrm{~mm} / \min$ (静 的） $2 \mathrm{~m} / \mathrm{sec}$ および $10 \mathrm{~m} / \mathrm{sec}$ の引張速度ごとに平滑 試験片の降伏応力, 破壊応力, 双晶発生応力, および伸 び，さらに切欠試験片の破壊応力，およびへき開破面率

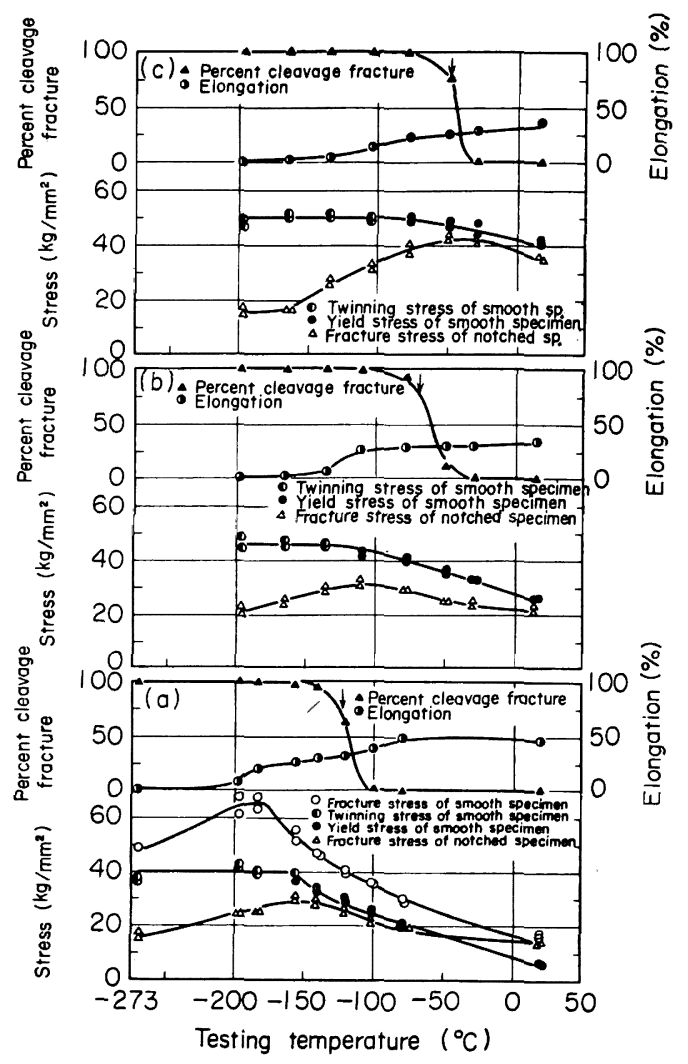

Fig. 2. Yield stress and elongation of smooth specimen, and fracure stress and percent cleavage fracture of notched specimen as a function of testing temperature examined at deformation rates of (a) $0.5 \mathrm{~mm} /$ min, (b) $2 \mathrm{~m} / \mathrm{sec}$, and (c) $10 \mathrm{~m} / \mathrm{sec}$. Arrows show the transition temperatures.

等の諸量の試験温度に対する变化を示す.これらより平 滑試験片の降伏応力は. いずれの場合にも温度の低下と ともに上昇しており，また静的引張に比べてひずみ速度 がきわかて大きい場合の降伏応力の上昇は著しいこと, しかしながら双晶発生応力の上昇はたかだか $10 \mathrm{~kg} / \mathrm{mm}^{2}$ 程度で温度およびひずみ速度にあまり依存しないことが 認められる. 伸びについては, 静的引張においては温度 の上昇とともに 2 段階の変化を示しているが, 衝揧引張 においては，2 種類の引張速度の場合とも，ほぼ同じ变 化をし, 静的引張における低温側の変化だけがあらわれ ており，とくに室温では静的引張に比べて小さい伸びを 示している. 切欠試験片の破壊強度については, $2 \mathrm{~m} /$

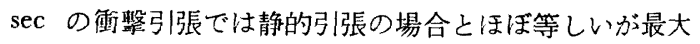
破壊応力の現われる温度がより高温側にずれている.こ れに比較して $10 \mathrm{~m} / \mathrm{sec}$ の引張速度の場合には, 低温側 
の破壊応力は他の変形速度の場合とほぼ等しいが，最大 破壊応力の値は大きく上昇し，またそれの現われる温度 もさらに高温側に移動している.

切欠試験片の破面を走査型電子顕微鏡で観察し，破面 遷移温度を，全破面に対するへき開型破面の割合が $75 \%$ となる温度として定義して求わたところ，引張速度が， $0.5 \mathrm{~mm} / \mathrm{min}, 2 \mathrm{~m} / \mathrm{sec}$ および $10 \mathrm{~m} / \mathrm{sec}$ の場合それ ぞれ $-122^{\circ},-68^{\circ}$ および $-48^{\circ} \mathrm{C}$ (Fig. 2 中の矢印) という結棵を得た.

\section{2 破壊鞄性値}

試験片が有限幅で両側に先端の鋭い切欠がついた板を 引張つた場合の破壊靶性值 $K$ は，まず第一近似として 次式のように求められる12).

$$
K=\sigma \sqrt{2 W \tan \pi C / W}
$$

ここに，W は試験片の幅の $1 / 2, C$ は切欠深さ， $\sigma$ は負荷応力である.

BOWIE は，試験片の形状効果をより詳細に考虑に入 れて，（1）式から求めた $K$ 值に対し，形状に基づく修 正倸数を切欠深さと試験片の幅の比の関数として算出し ている12). したがつて，今回の実験では，（1）式の $\sigma$

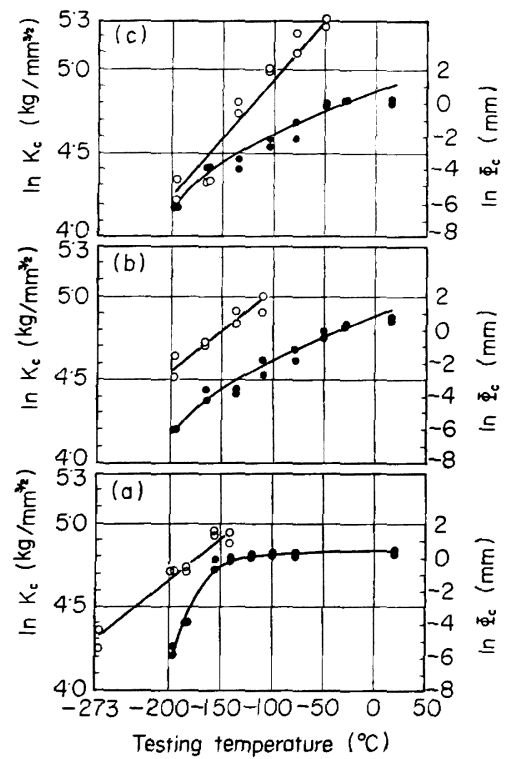

Fig. 3. Variation of fracture toughness value and critical COD value with testing temperature at deformation rates of (a) $0.5 \mathrm{~mm} /$ min, (b) $2 \mathrm{~m} / \mathrm{sec}$, and (c) $10 \mathrm{~m} / \mathrm{sec}$. Open circles show fracture toughness value $\mathrm{K}_{\mathrm{c}}$ and close circles critical COD value $\Phi_{c}$.
に切欠試験片の公称破壊応力を使用して $K$ 值を算出し， それに BOWIE の理論より $C / W=1 / 2$ の場合の修正係 数 1.05 を乘じたものを破壊䩓性值 $K_{c}$ として用いた. Fig. 3 にはこのようにして求めた $K_{c}$ 值を各引張速度ご とに○印で示す.

いつぽう，ORAWANの有効表面エネルギー $\gamma p^{13)}$ は $K_{c}$ 值と次式のように結ばれる。

$$
\gamma_{p}=K_{c}^{2} / 2 E \text {........ }
$$

ここに $E$ はヤング率である.（2）式を用いて各引張 速度ごとに計算した有効表面エネルギー $\gamma_{p}$ を Fig. 4 に 示す.これらの有効表面エネルギーの值は, 試験温度の 範囲では， $10^{6} \mathrm{erg} / \mathrm{cm}^{2}$ の行であり，実用鋼の大型試験 片を用いて求められた值 ${ }^{14)}$ に比較して，およそ1桁大き い値を示している.その理由としては，この実験に用い た試験片が薄板であるため切欠先端部付近の変形状態が 平面ひずみ状態になり難いことが考えられる.なお純鉄 のこの種の值は他に求められていないので比較すること はできなかつた。

\subsection{COD 值}

二層両側切欠試験片を用いて実測した限界 COD 值の 温度による変化を Fig. 3 の○印で示した.

WELLS ${ }^{8)}$ は，クラックの開口量を破壊のクライテリア として用いることを提案し，開口量 $\Phi_{c}$ をクラック長さ $C$, 負荷応力 $\sigma$ および降伏応力 $\sigma_{y}$ を用いて（3）式の ように表わした。

$$
\Phi_{c}=4 \sigma^{2} C / E_{y} \sqrt{1-\left(\sigma / \sigma_{y}\right)^{2}}
$$

ここで $E$ はヤング率である.

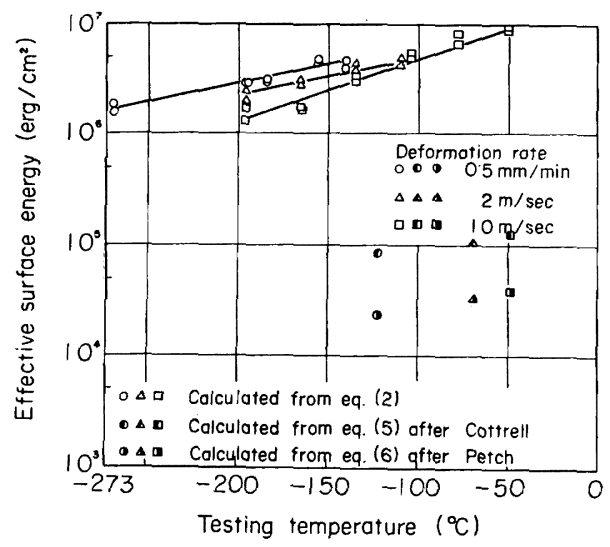

Fig. 4. Comparison between effective surface energies calculated from fracture toughness, and Cottrell and Petch's ductile-brittle transition theories as a fuunction of testing temperature. 


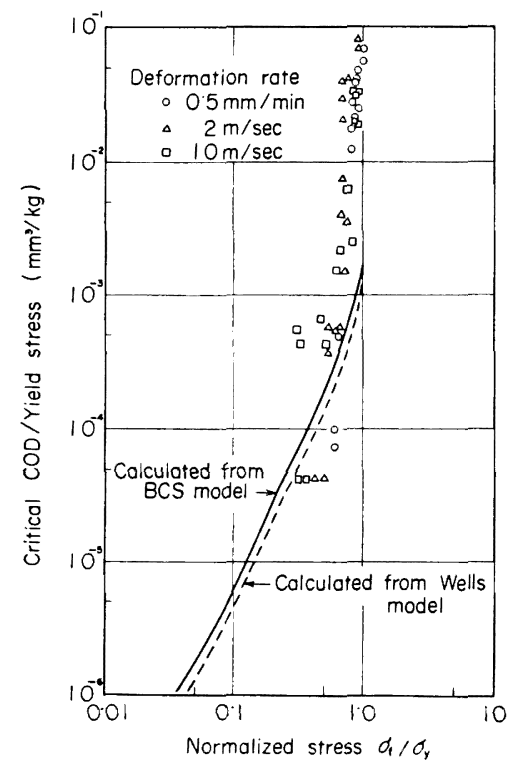

Fig. 5. Comparison of ratios of critical COD value to normalized stress between experimental value and calculated after Wells or BCS (Bilby, Cottrell, and Swinden) model.

$\sigma$ に破壊応力, $\sigma_{y}$ に平滑試片の降伏応力, $c$ に切欠 長さをとり，(3) 式を用いて計算した限界開口量 COD の值と実測値の比較を Fig. 5 に示す、いつぽう，BILBY ら9) は,転位モデルを用いて開口量 $\Phi_{c}$ を求める一般的な 方法を提案し, 開口型クラックに対しては, Dugdale の 結果とも一致するものとして次式を与えた.

$$
\Phi_{\mathrm{c}}=8\left(1-\nu^{2}\right) c \sigma_{y} \cdot \ln \left(\sec \pi \sigma / 2 \sigma_{y}\right) / \pi E
$$

ここでンはホアアソン比である. Fig. 5 には（4）式よ り計算した值をも示してある.Fig. 5 に見られるように WELLS およびBILBY らの式にしたがつて計算した COD の值と実測值は比較的よく一致しているが，破壊応力が 降伏応力に近うくにしたがい，実測值の方がより大きな 值を示す.この理由としては，この実験に用いた試験片 は，Fig. 1 に示したように，その板幅に比較して七刀切が 深いために, 切欠付近の net stress の值が gross stress の值に対して大きく，そのために $\sigma / \sigma_{y}$ の值が 1 に近い 場合は実測された COD 值が理論から推定された COD 值に比較して大きな值をとるものと考えられる.

限界 COD 值 $\Phi_{\mathrm{c}}$ に対するひずみ速度の影響について 考えてみると, Fig. 5 に示したように， 3 種類の引張速 度における $\Phi_{c} / \sigma_{y}$ と $\sigma / \sigma_{y}$ の関係は，一つの曲線上に
のつているものと考えられる. このことから，COD 值 に及ぼすひずみ速度の影響は，一般に降伏応力のひずみ 速度依存性を通じて表現しうるということができる.

\section{$3.4 \boldsymbol{K}_{c}$ 值および $\emptyset_{c}$ 值の温度, ならびにひずみ 速度依存性}

Fig. 3 に, 各引張速度ごとに, $K_{c}$ 值と $\Phi_{c}$ 值の自然対 数を温度に対して示した. 3 つの引張速度の場合とも遷 移温度より低い温度域で, $\ln K_{c}$ と温度 $T\left({ }^{\circ} \mathrm{K}\right)$ との間 にはほぼ直線的な関係が成り立ち, 温度の低下とともに $K_{c}$ 值も低下していくことが認められる. $\Phi_{c}$ 值について は，温度がほほ $-155^{\circ} \sim-165^{\circ} \mathrm{C}$ の領域を境としてそ れより低温および高温側の領域に対し, $\ln \Phi_{c}$ と温度 $T$ $\left({ }^{\circ} \mathrm{K}\right)$ の間にそれぞれ別のほぼ直線的な関係が成り立つ ことが認められる.引張速度の变化に対しては， $K_{c}$ 值は 同一の温度においては引張速度が大きくなるほど低い值 を示している. そして $K_{c}=K_{0} e^{T / T_{0}}$ (ここで $K_{0}, T_{0}$ は 定数である), のように表示した場合, 各引張速度につ いて最小二乘法で $K_{0}, T_{0}$ を定めると，脆性の程度を $K_{c}$ 㯈を用いて評洒した場合平均ひずみ速度が $8 \times 10 \mathrm{sec}^{-1}$ までは, 脆性の温度に対する变化割合はほぼ同じである

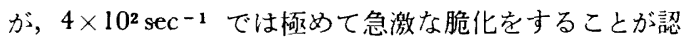
められた. $\Phi_{c}$ 值は, 静的引張と衝揧引張の場合では顕著 な差が現われ，前者に比較して後者の方が室温より低い 温度域ではずつと小さい值を示すが, 室温付近では, 両 者の差はみられない, そして, 衝整引張間では, 低温か ら室温付近まで， $\Phi_{c}$ 值は，ほほ同じ值をとり $K_{c}$ 值の 場合とは異なつた様相を示す. 以上を総合して， $K_{c}$ 值, $\Phi_{c}$ 值ともに温度，およびひずみ速度の関数であるが， 両者はこれらの因子に対し異なつた依存性を示してい る.

$K_{c}$ 值と透移温度との関係については, 引張速度が $2 \mathrm{~m}$ $\mathrm{sec}^{-1}$ までは遷移温度より十分低い温度域でないと $K_{c}$ 值は求まらないが, $10 \mathrm{~m} \mathrm{sec}^{-1}$ では遷移温度付近におい ても求めうる. $\Phi_{c}$ 值と遷移温度については，遷移温度 より十分低い温度域では， $\Phi_{c}$ 值は小であり，遷移温度 付近およびそれ以上の温度域では大きくなるが，温度に 対する $\Phi_{c}$ 值の変化は小さくなることが涩められる.

\section{5 破面の観察}

走査型電子顕微鏡等を用いて, 平滑および切欠試験片 の破面を中心とした観察を行なつた。平滑試験片では， 静的および衝撃引張ともに, 試験温度範囲の全域で全面 降伏が認められたのに対し, 切欠試験片は, 静的引張の 室温の場合のみ全面降伏が認められ, 静的引張の室温以 下の温度および衝撃引張の全温度域では顕著な切欠脆性 を呈した. 双晶の発生は平滑試験片の場合, 静的引張で 
は $-140^{\circ} \mathrm{C}$ 以下で, 衝慗引張では, いずれも $-30^{\circ} \mathrm{C}$ 以下で観察され，切欠試験片の場合は，静的および衝揧 引張の場合それぞれ $-100^{\circ}, 20^{\circ} \mathrm{C}$ 以下で起こり，切 欠の存在によりその発生が高温側に移ることなどが観察 された. 切欠の存在および衝揧引張下では, 双晶の発生 の温度範囲が拡大し単結晶の場合 ${ }^{15)}$ と同様に脆化に重要 な役割を果していることが認められた。

切欠試験片の破面については，室温から低温にかけて その破壊形態が大きく変化することが認められた，静的 引張では, 試験温度が $-269^{\circ},-196^{\circ}$ および $-183^{\circ} \mathrm{C}$ の場合双晶の発生ののちに脆性破壊し, 破面全体が入き
開状であつた. $-155^{\circ},-140^{\circ} \mathrm{C} に$ にいては，切久底付近 がすべりによつてある程度絞つたのちに, また $-120^{\circ} \mathrm{C}$ では延性破壊と同程度まで絞つたのちにそれぞれへき開 破壊した。 $-100^{\circ} \mathrm{C}$ 以上の高温側では完全な緎維状の延 性破壊をしていることが認められた。衝揧引張におい て, 引張速度が $2 \mathrm{~m} / \mathrm{sec}$ および $10 \mathrm{~m} / \mathrm{sec} て ゙$ 試験温度 がそれぞれ $-135^{\circ}$ および $-105^{\circ} \mathrm{C}$ 以下の低温域の場合 には，双晶が発生したのちに完全なへき開破面を呈する 脆性破壊が観察された。 引張速度が $2 \mathrm{~m} / \mathrm{sec}$ おび 10

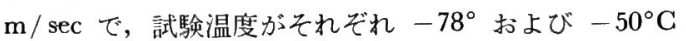
の場合には，切欠底付近が絞つたのちにへき開破壊を生

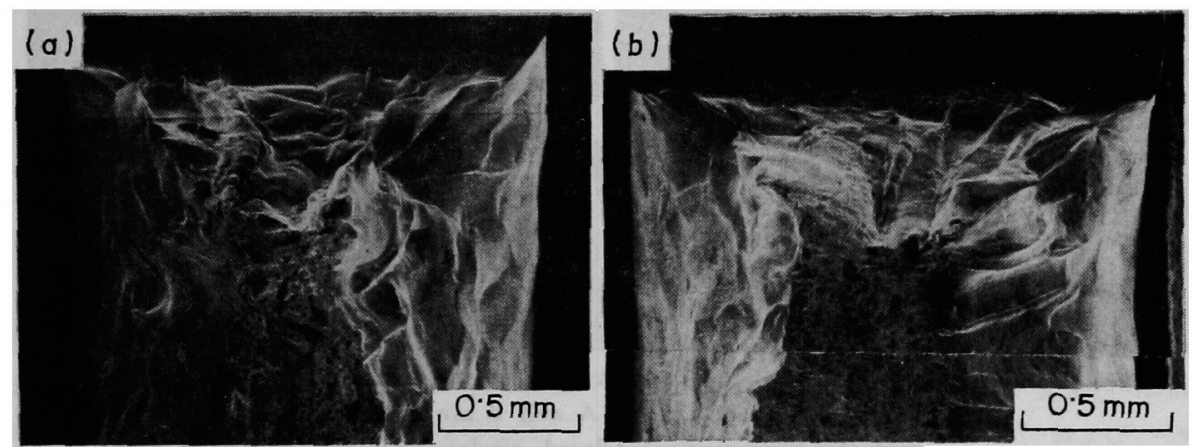

Photo. 1. Fracture surface in notch root at high testing temperature. (a) static $\left(0.5 \mathrm{~mm} / \mathrm{min},-100^{\circ} \mathrm{C}\right)$, (b) impact $\left(2 \mathrm{~m} / \mathrm{sec},-30^{\circ} \mathrm{C}\right)$
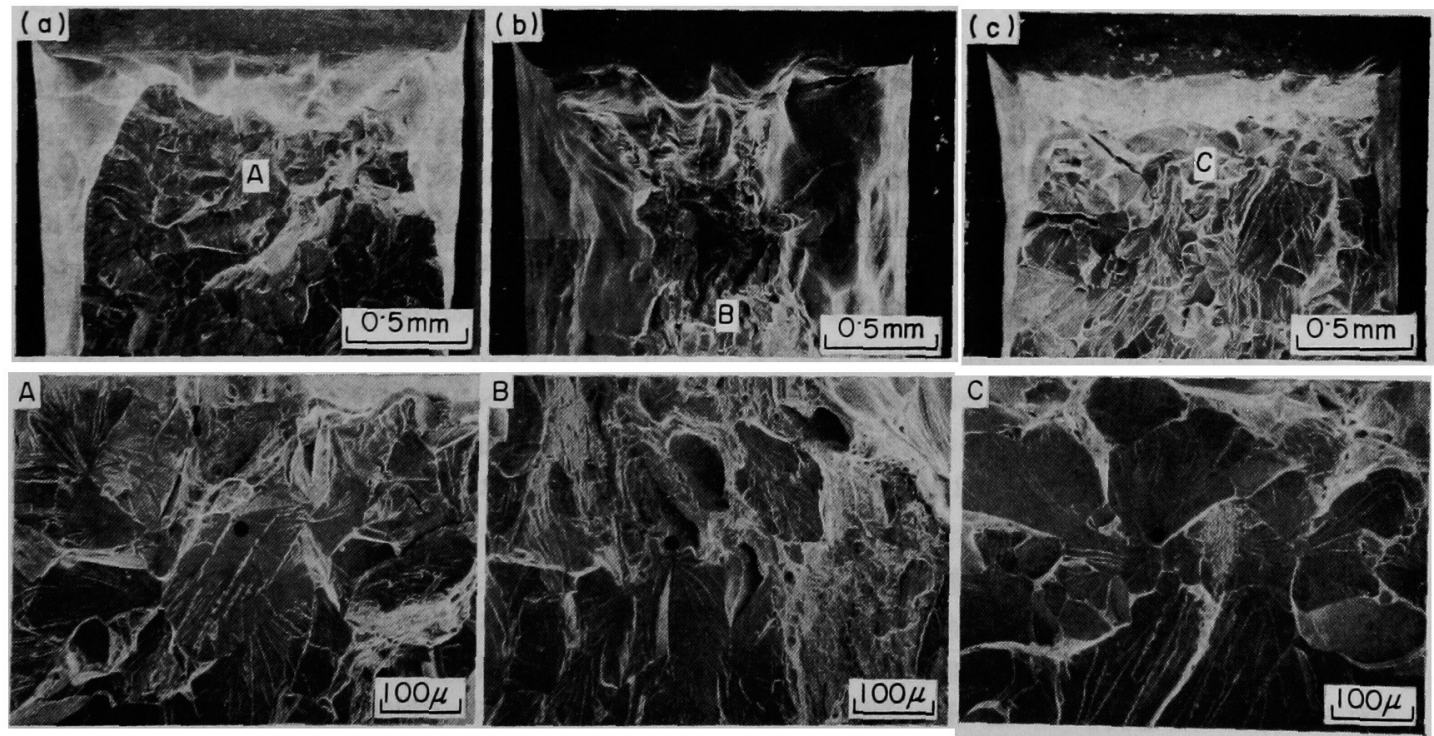

Photo. 2. Fracture surface in notch root at ductile-brittle transition temperature and the region of initiation of cleavage crack. A, B, and C are magnifications of notch root in (a), (b), and (c), respectively. Closed circles show the initiation point of cleavage fracture.

(a) static $\left(0.5 \mathrm{~mm} / \mathrm{min},-140^{\circ} \mathrm{C}\right)$, (b) static $\left(0.5 \mathrm{~mm} / \mathrm{min},-120^{\circ} \mathrm{C}\right)$, (c) impact $\left(2 \mathrm{~m} / \mathrm{sec},-78^{\circ} \mathrm{C}\right)$ 

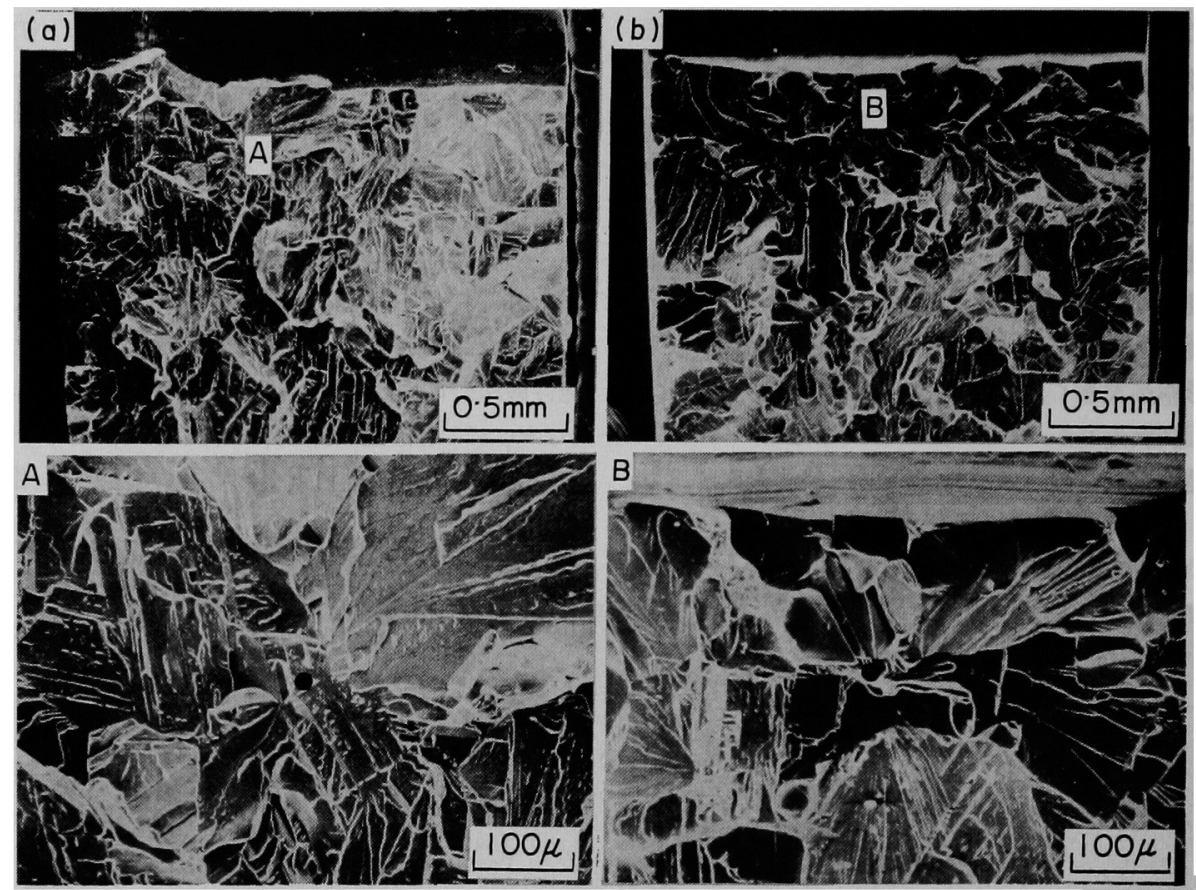

Photo. 3. Fracture surface in notch root at low testing temperature and the region of initiation of cleavage crack. A and B are magnifications of notch root in (a) and (b) respectively. Closed circles show the initiation point of cleavage fracture.

(a) static $\left(0.5 \mathrm{~mm} / \mathrm{min},-183^{\circ} \mathrm{C}\right)$, (b) impact $\left(10 \mathrm{~m} / \mathrm{sec},-105^{\circ} \mathrm{C}\right)$

じまた，それぞれ $-50^{\circ}$ および $-30^{\circ} \mathrm{C}$ 以上の高温 側では完全な繊維状の破面を示す延性破壊であつた.こ れらの結果ををとめると，切欠試験片を室温以下の温度 で引張つた場合, Photo. 1 に示すような完尒に繊維状 の延性破壊をする高温域, Photo. 2 に示すような切欠底 付近がすべりによつて絞つてから脆性破壊をする遷移温 度域 Photo. 3 にみられる切欠底付近から完全なへき開 破壊をする低温域の 3 領域に大別され，これは軟鋼の大 型切欠試験片についての他の実験結果と打执ね一致し ている. 遷移温度域は，静的引張の場合の $-155^{\circ} \sim$ $-100^{\circ} \mathrm{C}$ と比べて, 衝慗引張では, $2 \mathrm{~m} / \mathrm{sec}$ の場合は $-110^{\circ} \sim-30^{\circ} \mathrm{C}, 10 \mathrm{~m} / \sec$ の場合は $-105^{\circ} \sim-30^{\circ} \mathrm{C}$ 高温側に移動するだけでなくその温度域も拡大してい た、この結果は，純鉄丸棒試片を室温から低温までの温 度域で引張つた HAHN の実呀”とおおよそ一致する。

これらの 3 領域の破面の特徵を述べる，高温域では， 破面はすべての場合ディムプル模様を示していたが， Photo. 1 からわかるように, 静的引張では衝慗引㖘に 比べて大きく成長したボイドが多数みられるのに対し て, 衝等引張では，大きなボイドに成長しにくく，かつ
剪断によつて板厚方向に流れているのが観察された. 衝 撃引張の場合, 高温域に扎いても双晶が試験片表面上に 多数発生するのが認められたが, 破面上には観察されず, 高温域では双晶の破壊への寄与は小さいと考えられる. 遷移温度域, 低温域では, Photo. 2, 3 に示すように, 人 き開面に多数の双晶がみられ，また，リバーパターンや タング等の存在も認められ，これらは BEACHEM(6)の報告 とも一致している.

破面がおもにへき開面からなつている試験片について 切久底付近の破面観察から，破壊開始の位置を求めたと ころ，低温域では，Photo. 3 に示したように，多くの 場合切久底より少し内部で板厚中心に近い場所よりへき 開クラックが発生していることが知られた.これは完全 なへき開破壊では応力の 3 軸性の最も大きい部分からク ラックが発生伝播しやすいためであると考えられる。 た，切欠底付近がある程度絞つてからへき開破壊してい た試験片では，絞り方が小さい場合は, Photo. 2(a)の ように繊維状の変形とへき開の境界から 2 3 結晶粒だ け内部の結晶粒よりへき開を生じていた. 静的引張のみ に観察された僄移温度付近で完全に絞つてからへき開を 


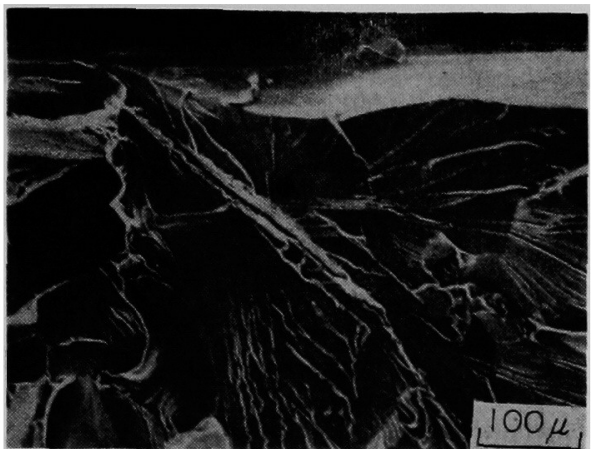

Photo. 4. Fracture initiation from twinning in notch root. Closed circle shows the initiation point of cleavage fracture. Impact $\left(10 \mathrm{~m} / \mathrm{sec},-105^{\circ} \mathrm{C}\right)$

生じる場合は, Photo. 2(b) に示すように, 絞つた部 分の先端からへき開が連続して発生していることが認め られた，そして，へき開クラックは，結晶粒のリバーパ ターンこの流れ方向の䙻察より，洼とえごの場合，精界 の近傍から発生していることが認められた. 双晶が原因 となつて発生した例は，P roto.4 に示すように少数なが ら認められ, Cohen らの絬果4とは異なつている. Photo. 2〜4において推定される破壞発生点を○印で示した。

\section{6 延性脆性要移寻度}

COTTRELLは（5）式のような延性脆性遷移条件を 提案した ${ }^{10)}$.

$$
\sigma_{y} k_{y} d^{1 / 2}=\xi \mu \gamma
$$

ここで $\sigma_{y}$ は降伏応力, $d$ は粒径, $k_{y}, \beta$ は定数, $\mu$ は剛性率， $\gamma$ は破面の有効表面エネルギーである。（5） 式を用いて, 各引張速度に対する切欠試験片の遷移温度 における有効表面エネルギーを平滑引張試呀より降伏応 力 $\sigma_{y}$ を求め, $\mu=8400 \mathrm{~kg} / \mathrm{mm}^{2}, \quad d=0.2 \mathrm{~mm}, \quad k_{y}=$ $1.9 \mathrm{~kg} / \mathrm{mm}^{3 / 2}$ および $\beta=1 / 3$ を代入して計算した結果 索 Fig. 4 に示す.

PETCH は，(6) 式のごとき遷移条件劣示した11．

$$
\left.\alpha T_{c}=\ln \mathrm{B}-\ln \{4 q \mu \gamma / k)-k\right\}+\ln d^{-1 / 2}
$$

ここで $q, \mathrm{~B}, k, \alpha$ は定数, $T_{c}$ は遷移温度, $d$ は粒径, $\mu$ は魝性率, $\gamma$ は有効表面エネルギーである.

（6）式に各引張速度ごとに，T，には破面遷移温度を $\beta, \alpha$ には平滑試験片の降伏応力-温度の関係を最小二雨 法から求めた值を代入し, $d=0.2 \mathrm{~mm}, q=0.33, k=1.9$ $\mathrm{kg} / \mathrm{mm}^{3 / 2}$ 17),$\mu=8400 \mathrm{~kg} / \mathrm{mm}^{3 / 2}$ として 有効表面 エネ ルギーを求め, その結思を Fig. 4 に示した. COTTRELL および PETCH の遷移温度に関する理諭から計算した有 効表面エネルギーの值は, 両者ともほぼ同じ值をとりこ
れらと IRWIN の K 理論より求めた值を比べると前者 は2 桁小さい值となつている.

平滑試験片の遷移温度については, COTTRELL がひず み速度をパラメーターとして（7）式を示した。

$$
1 / T r=-(k / u) \ln \dot{\varepsilon}+c
$$

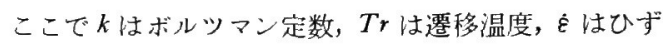
み速度, $u$ は活性化エネルギー, $c$ は定数である.

（7）式の遷移温度として，ひずみ速度 $3.33 \times 10^{-4}$, $8 \times 10$ および $4 \times 10^{2} \mathrm{sec}^{-1}$ に対して, 破面観察より求的 た遷移温度 $-155^{\circ},-125^{\circ}$ および $-95^{\circ} \mathrm{C}$ 走用い, $u$ を下降伏点の活性化エネルギー18) として計算すると， $c=6.88 \times 10^{-3}{ }^{\circ} \mathrm{K}^{-1}$ とすると(7) 式は十分に成り立つ ことが認められた.

\section{4. 結論}

純鉄の平滑および切久付板状試験片を室温から極低温

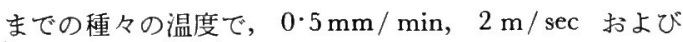
$10 \mathrm{~m} / \mathrm{sec} の 3$ 種の引張速度で弓張り, 次の結果を得た.

（1）切欠試験片の延性脆性遷移温度を，破面のへき 開卒が 75\% となる温度と定義して求めたところ, 引張 速度 $0.5 \mathrm{~mm} / \mathrm{min}, 2 \mathrm{~m} / \mathrm{sec}$, および $10 \mathrm{~m} / \mathrm{sec}$ に対 して，それぞれ， $-122^{\circ} ，-68^{\circ}$ 打よび $-48^{\circ} \mathrm{C}$ とな つた.

切久試験片の破壊強度は，ある臨界温度以下では温度 の低下とともに減少した。

（2）破壊靶性値 $\mathrm{K}_{c}$ 上限界 COD 值 $\Phi_{c}$ は異なつ た温度およびひずみ速度依存性を示した， $K_{c}$ 值は， In $K_{c}$ と $T\left({ }^{\circ} \mathrm{K}\right)$ の間では, 各引張速度とも直線関倸が成 り立つが，脆化の温度に対する割合は，平均ひずみ速度 が $10^{2} \mathrm{sec}^{-1}$ 付近を境とし，それ以上のひずみ速度では 急な脆化をすることが示された． $\Phi_{c}$ 值は，静的引張と 衝揧引張との間に顕著な差があらわれ，一般に室温付近 を除いて低温になるにしたがい，前者より後者の方がず つと小さい值を示した.

（3）BILBY らおよび Wells のモデルを用いて計算 した限界 COD 值を実測值と比較した結果, $\sigma_{f} / \sigma_{y} \leqq$ 0.6 の範囲では計算值と実測值は大体一致した。 また, 実測値は引張速度にかかわらず降伏応力を通じて 1 曲線 上にのることが示された。

（4）切欠試験片の破壊形態は, 完全に繊維状の高温 域, 切欠底が絞れてからへき開破壊する遷移温度域およ び完全にへき開する低温域の 3 つに分類された. そし て, 引張速度が大きくなるほど, 遷移温度域および低温 域は，より高温側に移動した.

（5）へき開クラックの発生場所は，多くの場合切欠 
底より 2 ないし 3 結晶粒分だけ内部の板厚中心付近であ ることが知られた。 また，切欠試験片では，双晶が，ク ラック発生の起点になりうることも確認された.

(6) Cottrell および Petch らの遷移温度理論か ら求めた表面エネルギー值と破壊鞠性值より求めたもの を比較した結果, 前者は $10^{4} \mathrm{erg} / \mathrm{cm}^{2}$ の桁で, 後者の $1 / 100$ 程度であつた。

\section{6. 謝辞}

純鉄の溶解をして下さつた石川島播磨重工業(株)技術 研究所の雑賀喜規部長, 福井浣一主任に厚く㧍礼申し上 ぼます。また，液体へリウムでの実験でお世話になつた 東京芝浦電気 (株) 総合研究所の 福島英二氏に深㴬し す. 実験遂行上, 多大の協力をされた本学の堀江史郎技 官, 学部学生の加志元史君 (現, 黑田精工(株)）に感謝 いたします。

\section{交献}

1) G. T. Hahn, B. L. Averbach, $W . S$. Owen and $M$. CoHEv: "Initiation of Cleavage Microcracks in Pollycrystalline Iron and Steel", Fracture ed. B. L. Averbach, (1959), p. 91 [MIT Press]

2) $T$. Nakamura and $A$. Matiuda: Proc. ICSTIS Suppl. Trans. ISIJ, 11 (1971), p. 982

3 ) N. J. Pетсh: J. Iron Steel Inst., 174 (1953),
p. 25

4) G. C. Macmahon and M. Cohen: Act. Met., 13 (1965), p. 591

$5) H . L L . D$. Pugh, S. S. Chang and $B . E$. Hopkins: Phil. Mag., 8 (1963), p. 753

6) G. R. IRwin: "Fracture Dynamics", Fracturing of Metals, (1948), p. 147 [ASM]

7) G. R. Irwin: J. Appl. Mech., 24 (1957), p. 361

8 ) A. A. Wells: Brit. Weld. J., 10 (1963), p. 563

9 ) B. $A$. Bilby, $A . H$. Cottrell and $K$. $H$. Swinden: Proc. Roy. Soc., A272 (1963), p. 304

10) A. H. Cottrell: Trans. AIME, 212 (1958), p. 192

11) N. J. Ретсh: Phil. Mag. 3 (1958), p. 1089

12) O. L. Bowie: J. Appl. Mech., 31 (1964), p. 208

13) E. Orowan: Weld. J., 34 (1955), p. 157-s

14) $K$. Ikeda, $Y$. Akita and $H$. Kihara: Weld. J., 46 (1967), p. 133-s

15) J. Harding: Proc. Roy. Soc., A299 (1967), p. 464

16) C.D. Beachem: "Microscopic Fracture Process", Fracture ed. H. Liebowitz vol. 1 (1968), p. 244 [Academic Press]

17) 作井誠太, 森勉: 日本金属学会誌, 28 (1964), p. 443

18) H. ConRad: J. Iron Steel Inst., 182 (1961), p. 364 